\title{
Science for Policy: My Year on Capitol Hill
}

\section{Margaret D. Callahan}

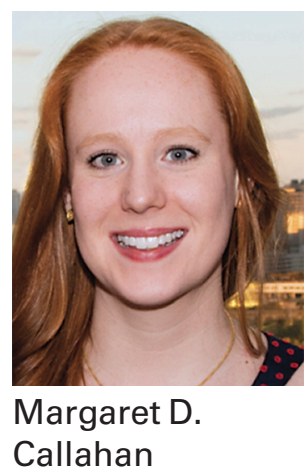

This past year, I had the incredible privilege of serving as the AMS Congressional Fellow. I was one of thirty-six $\mathrm{PhD}$ scientists with a wide range of scientific backgrounds serving in Congress-in personal offices and on committee staff, in both chambers, and on both sides of the aisle. Although the American Association for the Advancement of Science (AAAS) organizes the Congressional Science and Engineering Fellowship program, nearly all of the Fellows in my cohort were sponsored by scientific associations like AMS. The Congressional Fellows joined over 200 Executive Branch Fellows and a single Judicial Branch Fellow to form the 2017-2018 Fellowship class. The goal of the Fellowship is to bring scientific perspective and technical expertise to the legislative process while affording scientists a voice in the conversations that shape our nation's public policy. Given that less than three percent of Congress has a background in science or engineering and the rapidly increasing rate at which our lawmakers are forced to make decisions within highly technical and scientific frameworks, it is more important than ever that scientists are part of the legislative process.

To varying degrees, Congressional Fellows engage in both "science for policy" and "policy for science." Science for policy can be viewed as the use of scientific knowledge or processes to assist in or improve decision-making, whereas policy for science refers to how the federal government funds or structures science research. During my Fellowship year, which I spent working in the office of Senator Amy Klobuchar of Minnesota on issues pertaining to education and workforce development, I primarily

Margaret D. Callahan works as a foreign affairs officer with the US State Department.

For permission to reprint this article, please contact: reprint - permission@ams .org.

DOI: https://dx.doi.org/10.1090/noti 1784 engaged in science for policy. I had the opportunity to become knowledgeable about a wide range of timely issues, including protections for student loan borrowers, access to apprenticeships and career training programs, innovations in STEM education, the rights of labor unions, child care shortages, and so much more.

Over the course of the year, I participated in many different aspects of the legislative process, and no two days were alike. I attended hearings and briefings on topics of interest and relevance to the senator and drafted meeting memos, legislative background materials, letters, and talking points. I researched and analyzed bills and letters in order to help advise the senator on whether or not she should lend her support (typically in the form of a cosponsorship or signature, respectively). I worked with Minnesota experts and stakeholders, colleagues on both sides of the aisle, and legislative counsel to draft legislation, and strategized with senior staff on how to get new bills introduced and passed. I took meetings with constituent, advocacy, and industry groups, learning about important issues affecting Minnesotans and building helpful connections with people on the ground.

While I did not have the opportunity to leverage my specific training as an applied mathematician to further my boss' policy priorities, I did use the skills I obtained over the course of my doctoral studies and in doing mathematical research. My research skills and analytical mindset were useful in the vetting of new legislation that other senators had asked Senator Klobuchar to cosponsor. Problem solving, critical thinking, and creativity lent themselves to the development of new ideas-legislative and otherwise-to address problems facing people in Minnesota and across the country. In researching and drafting new legislation, I was able to bring my own sense of scientific rigor to the process, whether by ensuring that data supports the foundation of a particular bill or by demanding clarity and logical flow in the language. A Congressional Fellow has 
the opportunity to be more than a voice for science and for evidence-based policy-making in their host office-they can bring elements of the scientific process into their work every day.

In addition to the personal and professional satisfaction of contributing in a tangible way to the formulation of policy solutions to the problems facing our nation, $\mathrm{PhD}$ scientists have a great deal to gain from an experience working on Capitol Hill. Over the course of my Fellowship year, I established a broad and diverse professional network consisting of fellow AAAS Fellows, colleagues from my Senate office, and science policy professionals across the DC area. I developed a comprehensive understanding of the policy-making process and sense of how scientists fit into that process. I gained the ability to multitask in an intense and fast-paced work environment and further strengthened my skills in communication to a wide variety of audiences. The Fellowship gave me the opportunity to contribute my skills and experiences as a mathematician-quite unique to Capitol Hill-to the policy-making process, and it helped me see how much the work and perspectives of scientists are valued by lawmakers.

I had a truly fantastic experience as the AMS Congressional Fellow. Before starting the Fellowship, in part because of the current political climate, many people expressed skepticism about the experience I was likely to have and what I would be able to realistically contribute. However, through this experience-in particular, in working with some of the smartest, most dedicated and hardworking people in my Senate office-I have become, if anything, less cynical about the work that is done on Capitol Hill. Most people I have met here are motivated by an honest desire to serve their country and to improve peoples' lives. The experience has been humbling and inspiring and I have learned more than I ever dared hope. I am immensely grateful to AMS for sponsoring this Fellowship and for affording me the honor of serving as its Fellow.

The AMS sponsors one fellowship placement in Congress each year. Application deadline for the AMS Congressional Fellowship is February 15, 2019. Learn more and apply at http://bit. 1y/2LaVL1B.

There will be an information session about this Fellowship at the Joint Mathematics Meetings in Baltimore, MD on Friday, January 18, 2019, at 4:30 pm in Room 316 of the Baltimore Convention Center. Come and find out more about this unique opportunity!

Credits

Author headshot is courtesy of the author. 